\title{
Penentuan Pola Pembelian Konsumen pada Indomaret GKB Gresik dengan Metode FP-Growth
}

\author{
Amir Setiawan ${ }^{1}$, dan Indra Gita Anugrah ${ }^{2}$ \\ ${ }^{1}$ Universitas Muhammadiyah Gresik \\ Program Studi Teknik Informatika \\ Jl. Sumatera No.101, Gresik, 61121 \\ author's e-mail: amir_set21@yahoo.com, indragitaanugrah@umg.ac.id
}

\begin{abstract}
Abstrak - Tidak bisa dimungkiri lagi bahwa minimarket masih menjadi tempat favorit masyarakat Indonesia untuk membeli berbagai macam kebutuhan mereka, salah satu diantaranya adalah Indomaret. Di Indomaret sendiri banyak sekali pengunjung atau konsumen yang lalu lalang keluar masuk toko untuk membeli barang keperluan mereka. Dengan banyaknya konsumen yang keluar masuk toko dan membeli barang yang sangat beraneka ragam itu, terdapat kesulitan untuk menentukan item mana yang masuk kedalam item laku atau sebaliknya. Dirasa perlu diadakan pengujian terkait bagaimana pola pembelian konsumen yang terjadi dan apa item yang paling sering dibeli oleh konsumen dengan banyaknya jenis barang yang disediakan oleh toko tersebut. Dengan menerapkan metode Market Basket Analysis didapatkan sebuah pola asosiasi terkait dengan banyaknya barang yang dilakukan pembelian bersamaan untuk selanjutnya dapat dijadikan pertimbangan sebagai item bandage promosi. Metode FP-Growth dirasa tepat untuk menggambarkan masalah yang terjadi tersebut, karena metode ini mempunyai pattern yang membuat pengolahan data menjadi lebih cepat dalam menentukan pola asosiasi. Menggunakan data transaksi yang terjadi selama 1 bulan pada salah satu toko Indomaret di daerah GKB Gresik yang kemudian diolah dan dianalisis menggunakan program aplikasi WEKA, sehingga ditemukanlah pola pasangan item terbaik yang memenuhi syarat - syarat dalam aturan asosiasi yang ditetapkan.
\end{abstract}

Kata kunci: Association Rule, FP-Growth, Data Mining, Itemset, WEKA

\section{Pendahuluan}

Di era modern saat ini telah banyak dijumpai toko - toko yang bertemakan toko modern seperti minimarket. Mulai dari minimarket lokal, nasional bahkan internasional sudah banyak berdiri di Indonesia. Salah satu nama yang sangat familiar adalah Indomaret. Indomaret merupakan minimarket atau toko yang bertaraf nasional dengan hampir ada sekitar 14 ribu gerai yang tersebar di seluruh Indonesia. Berbagai macam kebutuhan dapat ditemukan di toko tersebut. Mulai dari kebutuhan harian hingga bulanan ataupun kebutuhan sementara. Disana juga menyediakan berbagai macam pembayaran elektronik seperti angsuran, pulsa, token listrik hingga layanan pembayaran untuk $e$ commerce.

Dengan mengamati jumlah konsumen yang keluar masuk toko dan membeli barang keperluan mereka serta berbagai macam barang yang dijual disana, maka akan sulit sekali menentukan kondisi barang yang dijual di toko tersebut termasuk laku atau kurang laku bahkan tidak laku. Dengan mengamati hal tersebut penulis ingin melalukan penelitian tentang barang apakah yang paling sering dibeli oleh konsumen secara bersamaan. Tujuan dilakukannya penelitian berikut ini adalah untuk menentukan pola pembelian konsumen yang paling banyak dibelli secara bersamaan sehingga bisa dijadikan sebagai item bandage. Bandage adalah memasangkan 2 item atau lebih item yang berbeda jenis dengan harga tertentu dengan tujuan promosi.

Penelitian kali ini merujuk pada data detail transaksi yang terjadi di toko setiap harinya. Data didapatkan dari hasil eksportan dari komputer server atas detail transaksi penjualan yang terjadi toko selama bulan Juli 2019. Data tersebut adalah berupa data csv. Data csv sendiri adalah berupa data text dengan pola tertentu yang sering digunakan kedalam bahasa pemrograman karena ukurannya yang kecil.

Metode yang dirasa cocok untuk kasus ini adalah metode data mining asosiasi. Metode asosiasi merupakan sebuah metode data mining yang juga dikenal dengan nama association rule. Metode asosiasi sering juga disebut dengan metode keranjang belanja atau Market Basket Analysis karena biasanya konsumen jika akan membeli barang kebutuhan mereka pasti menggunakan keranjang yang biasanya memang sudah tersedia di toko. Metode yang akan digunakan adalah metode FP-Growth (Frequent Pattern Growth) dengan bantuan aplikasi WEKA 3.9 .

\section{Tinjauan Pustaka}

2.1. Market Basket Analysis (MBA)

Market Basket Analysis atau juga dikenal dengan analisis keranjang belanja adalah suatu metode untuk menganalisa dan pembentukan asosiasi antara beberapa barang yang berbeda yang diletakkan 
konsumen kedalam sebuah keranjang belanja pada suatu pembelian tertentu. Analisis data transaksi dapat menunjukkan hasil terkait pola barang yang sering dibeli[13]. Metode ini memanfaatkan data transaksi untuk kemudian dianalisa sehingga ditemukan pola item - item yang dibeli oleh konsumen secara bersamaan dalam suatu transaksi [1].

Manfaat diterapkannya metode ini antara lain untuk menentukan lokasi atas barang yang sering dibeli bersamaan itu agar diletakkan berdekatan dan juga untuk memasangkan item tersebut menjadi item bundling dengan promosi tertentu.

\subsection{Data Mining}

Data mining merupakan proses memperoleh informasi dengan mencari pola dan hubungan yang tersembunyi pada tumpukan data [2]. Data mining merupakan salah satu disiplin ilmu yang sebagian besar terbuka untuk dunia. Data mining juga disebut sebagai Knowladge Discovery in Database (KDD), yaitu kegiatan pengumpulan, pemakaian data lampau untuk menemukan pola atau hubungan terhadap data yang ukurannya besar. Data mining ini juga bisa digunakan untuk membantu dalam pengambilan keputusan [3][12]. Berdasarkan fungsinya data mining dikelompokkan menjadi beberapa kelompok sebagai berikut [4]:

a. Deskripsi (descripsion), untuk memberi ringkasan untuk data yang jumlahnya sangat besar dan banyak jenisnya.

b. Estimasi (estimation), untuk menebak - nebak nilai yang belum diketahui, contoh menerka penghasilan seseorang berdasarkan informasi pekerjaan orang tersebut.

c. Prediksi (prediction), untuk memperkirakan nilai yang mungkin akan terjadi di masa yang akan datang, contoh prediksi stok bahan baku untuk beberapa bulan yang akan datang.

d. Klasifikasi (classification), untuk membagi data menjadi beberapa label kelas untuk objek yang sudah diketahui hasilnya dan memperkirakan kelas berdasarkan objek yang belum diketahui labelnya.

e. Pengelompokan (clustering), untuk mengelompokkan sejumlah data yang mempunyai suatu karakteristik tertentu.

f. Asosiasi (association), untuk mengetahui pola pengelompokan data dalam suatu kondisi tertentu.

\subsection{Association Rule}

Analisis asosiasi atau disebut association rule adalah merupakan teknik data mining yang digunakan untuk menentukan aturan asosiatif yang memenuhi minsup (minimum support) dan minconf (minimum confidence) [5]. Association rule adalah suatu teknik untuk menemukan hubungan antara item - item dalam sebuah dataset. Association rule memiliki bentuk LHS (Left Hand Shake) $\Rightarrow>$ RHS (Right Hand Shake) yang artinya adalah jika setiap item didalam LHS dibeli maka membeli juga item yang ada di RHS. Yang terpenting untuk membentuk sebuah rule adalah Support dan Confidence [6].

Support adalah nilai pendukung yang menunjukkan dominasi atau kontribusi dari suatu itemset dari total keseluruhan transkasi. Sedangkan Confidence adalah nilai kepercayaan yang mex`nunjukkan hubungan antara dua itemset atau LHS dan RHS secara conditional (berdasarkan kondisi terentu) [7]. Rumus umum mencari nilai support dan nilai confidence adalah sebagai berikut: Si

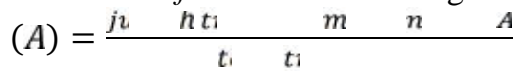

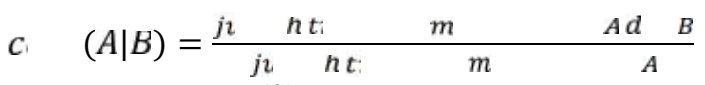

(2)

Berikut ini adalah sebuah contoh rekap struk penjualan yang digunakan untuk proses asosiasi. 


\begin{tabular}{|c|c|c|c|c|c|}
\hline No Transaksi & \multicolumn{5}{|c|}{ Jenis Barang } \\
\hline TR-001 & Minyak Goreng & Gula & Kopi & Teh & Susu \\
\hline TR-002 & Air Mineral & Susu & Snack & & \\
\hline TR-003 & Buku & Pensil & & & \\
\hline TR-004 & Permen & Gula & & & \\
\hline TR-005 & Pensil & & & & \\
\hline TR-006 & Snack & Air Mineral & & & \\
\hline TR-007 & Gula & Kopi & & & \\
\hline TR-008 & Susu & Teh & & & \\
\hline TR-009 & Gula & Buku & Pulpen & & \\
\hline TR-010 & Air Mineral & Minyak Goreng & Kopi & & \\
\hline TR-011 & Snack & Gula & Kopi & Buku & \\
\hline TR-012 & Buku & & & & \\
\hline TR-013 & Permen & Snack & & & \\
\hline TR-014 & Kopi & Teh & Susu & & \\
\hline TR-015 & Susu & & & & \\
\hline
\end{tabular}

Tabel 1. Contoh tabel transaksi per struk

Dari Tabel 1. dapat diketahui bahwa terdapat 15 frekuensi kemunculan atas item - item yang dibeli jenis transaksi dengan beberapa pola item - item tersebut sebagai berikut: yang terbeli. Dari tabel tersebut dapat dihitung

\begin{tabular}{|c|c|c|}
\hline No & Jenis Barang & Frekuensi \\
\hline 1 & Minyak Goreng & 2 \\
\hline 2 & Gula & 5 \\
\hline 3 & Kopi & 5 \\
\hline 4 & Teh & 3 \\
\hline 5 & Susu & 5 \\
\hline 6 & Air Mineral & 3 \\
\hline 7 & Snack & 4 \\
\hline 8 & Buku & 4 \\
\hline 9 & Pensil & 2 \\
\hline 10 & Permen & 2 \\
\hline 11 & Pulpen & 2 \\
\hline
\end{tabular}

Tabel 2. Tabel frekuensi tiap item (bagian kanan adalah setelah diurutkan berdasarkan frekuensi tertinggi)

Dari Tabel 2. misal ditetapkan nilai minsup (minimum support) sebesar $20 \%$, maka untuk item- item yang dibawah minsup dihilangkan pada proses selanjutnya. 


\begin{tabular}{|c|c|c|c|}
\hline No & Jenis Barang & Frekuensi & Support \\
\hline 1 & Gula & 5 & $33 \%$ \\
\hline 2 & Kopi & 5 & $33 \%$ \\
\hline 3 & Susu & 5 & $33 \%$ \\
\hline 4 & Snack & 4 & $27 \%$ \\
\hline 5 & Buku & 4 & $27 \%$ \\
\hline 6 & Teh & 3 & $20 \%$ \\
\hline 7 & Air Mineral & 3 & $20 \%$ \\
\hline 8 & Minyak Goreng & 2 & $13 \%$ \\
\hline 9 & Pensil & 2 & $13 \%$ \\
\hline 10 & Permen & 2 & $13 \%$ \\
\hline 11 & Pulpen & 2 & $13 \%$ \\
\hline
\end{tabular}

Tabel 3. Menunjukkan nilai support tiap itemset (itemset dibawah 20\% dihilangkan)

Pada Tabel 3 terdapat nilai support yang didapat dengan menerapkan persamaan (1). Item yang tidak memenuhi syarat minsup seperti yang ditunjukkan oleh Tabel 3 kemudian dihilangkan. Selanjutnya adalah kembali ke pola awal atau Tabel 1 namun dengan item yang sudah dihilangkan sesuai Tabel 3. Seperti berikut:

\begin{tabular}{|c|c|c|c|c|c|}
\hline No Transaksi & \multicolumn{5}{|c|}{ Jenis Barang } \\
\hline TR-001 & & Gula & Kopi & Teh & Susu \\
\hline TR-002 & Air Mineral & Susu & Snack & & \\
\hline TR-003 & Buku & & & & \\
\hline TR-004 & & Gula & & & \\
\hline TR-005 & & & & & \\
\hline TR-006 & Snack & Air Mineral & & & \\
\hline TR-007 & Gula & Kopi & & & \\
\hline TR-008 & Susu & Teh & & & \\
\hline TR-009 & Gula & Buku & & & \\
\hline TR-010 & Air Mineral & & Kopi & & \\
\hline TR-011 & Snack & Gula & Kopi & Buku & \\
\hline TR-012 & Buku & & & & \\
\hline TR-013 & & Snack & & & \\
\hline TR-014 & Kopi & Teh & Susu & & \\
\hline TR-015 & Susu & & & & \\
\hline
\end{tabular}

Tabel 4. Detail transaksi dengan item dibawah minsup dihilangkan

Dibuat kembali ke pola transaksi awal dengan menghilangkan item yang syarat minsupnya tidak terpenuhi terlihat pada Tabel 4. Selanjutnya adalah menyusun pola pasangan antar itemset. Dalam contoh tersebut ditetapkan nilai minconf (minimum confidence) sebesar $60 \%$, untuk penentuan nilai confidence didapatkan dengan menerapkan persamaan (2). Terdapat 4 pasang itemset yang memenuhi syarat minsup maupun minconf seperti Tabel 5 berikut: 


\begin{tabular}{|c|c|c|}
\hline Rule & Support & Confidence \\
\hline Kopi => Gula & $20 \%$ & $60 \%$ \\
\hline Gula => Kopi & $20 \%$ & $60 \%$ \\
\hline Susu => Teh & $20 \%$ & $60 \%$ \\
\hline Teh => Susu & $20 \%$ & $100 \%$ \\
\hline
\end{tabular}

Tabel 5. Hasil akhir pola itemset yang memenuhi syarat minsup dan minconf

\subsection{FP-Growth (Frequent Pattern Growth)}

FP-Growth merupakan sebuah algoritma yang dipergunakan untuk menentukan kelompok data yang sering muncul secara bersamaan dalam sebuah kumpulan data. FP-Growth adalah pengembangan dari algoritma apriori dengan menghilangkan proses candidate generation. Candidate generation adalah pencarian himpunan kandidat dari semua pola yang ada dan kemudian kandidat terpilih dicocokkan dengan jumlah kemunculan pola tersebut sebanyak data yang ada dalam database [8].

Algoritma FP-Growth menggunakan konsep tree dalam menentukan pencarian frequent itemset, sehingga prosesnya menjadi lebih cepat dari apriori. Algoritma tree yang digunakan oleh FP-Growth disebut dengan FP-tree. FP-tree dibangun dengan cara menggambarkan setiap data transaksi kedalam setiap jalur tertentu dalam FP-tree. Semakin banyak data transaksi dengan item sama, maka proses pemetaan fp-tree semakin efektif [9].

FP-Growth dibagi kedalam tiga tahap utama, yaitu : a. Tahap pembangkitan Conditional Pattern Base merupakan subdatabase yang berisikan prefix path (lintasan prefix) dan suffix pattern (pola akhiran). Pembangkitan tersebut didapat lewat FP-tree yang sudah dibangun sebelumnya.

b. Tahap pembangkitan Conditional FP-tree. Pada tahap ini nilai support pada setiap conditional pattern base dijumlahkan atau disebut sebagai support count, kemudian setiap item yang memenuhi minsup akan dibangkitkan dengan conditional FP-tree.

c. Tahap pencarian frequent itemset. Jika Conditional FP-tree adalah single path (lintasan tunggal), maka frequent itemset didapat dengan membuat kombinasi item dari setiap conditional FP-tree, jika bukan maka dibuat pembangkitan FP-Growth secara rekursif [10].

Dari Tabel 4 diurutkan berdasarkan frekuensi tertinggi yang didapat pada Tabel 3, sehingga akan membentuk sebuah pattern yang seragam kemudian diimplementasikan ke dalam format tree.

\begin{tabular}{|c|c|c|c|c|c|}
\hline No Transaksi & \multicolumn{5}{|c|}{ Jenis Barang } \\
\hline TR-001 & Gula & Kopi & Susu & Teh & \\
\hline TR-002 & Susu & Snack & Air Mineral & & \\
\hline TR-003 & Buku & & & & \\
\hline TR-004 & Gula & & & & \\
\hline TR-005 & & & & & \\
\hline TR-006 & Snack & Air Mineral & & & \\
\hline TR-007 & Gula & Kopi & & & \\
\hline TR-008 & Susu & Teh & & & \\
\hline TR-009 & Gula & Buku & & & \\
\hline TR-010 & Kopi & Air Mineral & & & \\
\hline TR-011 & Gula & Kopi & Snack & Buku & \\
\hline TR-012 & Buku & & & & \\
\hline TR-013 & Snack & & & & \\
\hline TR-014 & Kopi & Susu & Teh & & \\
\hline TR-015 & Susu & & & & \\
\hline
\end{tabular}

Tabel 6. Detail pembelian item per struk yang sudah diurutkan 
Tabel 6 menunjukan pola pattern yang kemudian dapat dibuat bentuk tree-nya seperti yang

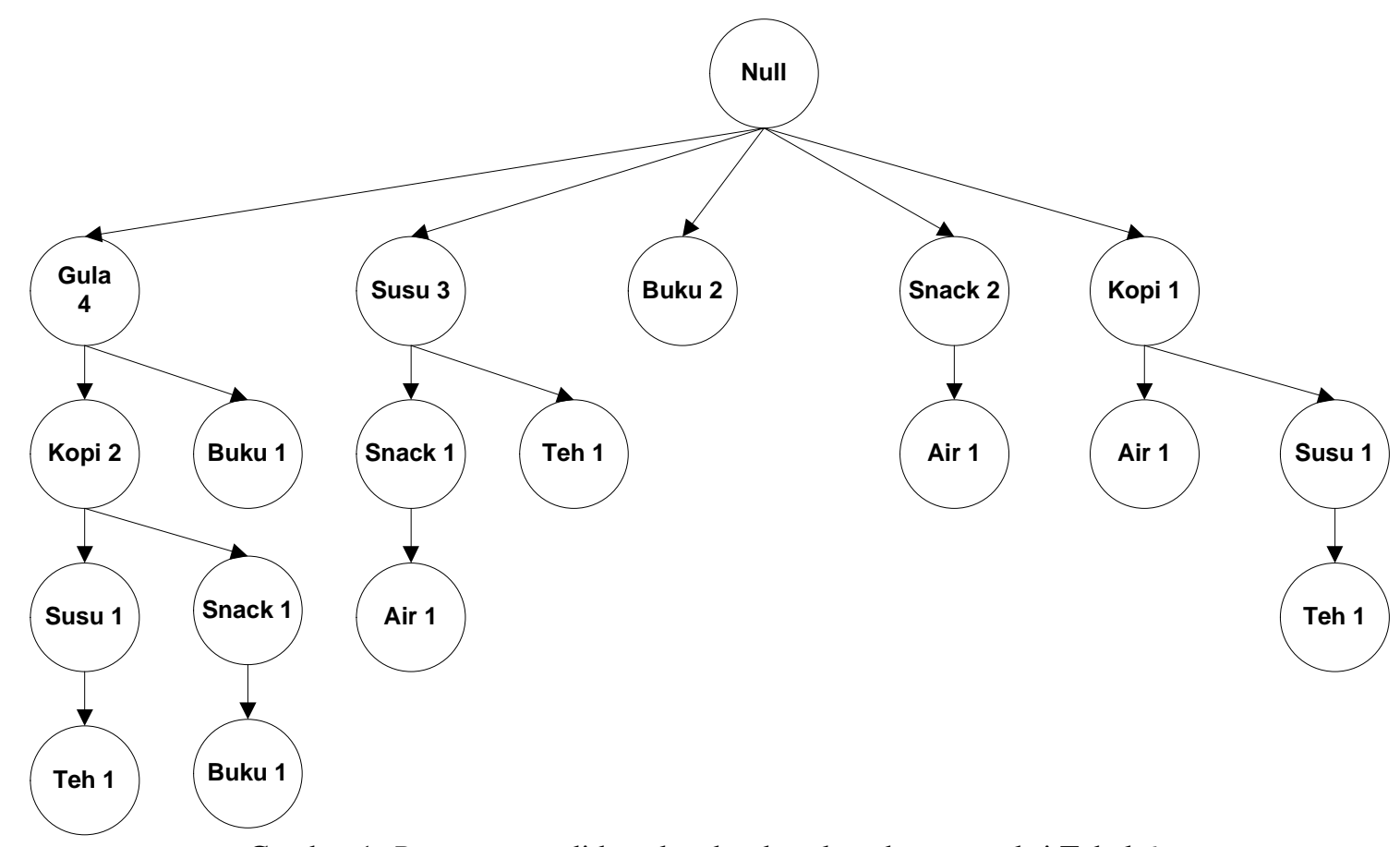

Gambar 1. Pattern yang didapatkan berdasarkan data transaksi Tabel 6.

Setelah dilakukan penyesuain pattern seperti yang ditujukkan oleh Tabel 6. kemudian dibuat pattern FP-Growth tahap 1 sampai 3, maka didapatkan hasilnya seperti pada Gambar 1 .

\subsection{WEKA}

WEKA merupakan sebuah paket tools machine learning yang terbilang praktis. Singkatan dari Waikato Environment for Knowledge Analysis, yang diproduksi di Universitas Waikato, New Zealand yang berfungsi untuk pendidikan, penelitian dan berbagai aplikasi. WEKA sanggup menyelesaikan permasalahan permasalahan data mining yang terdapat di dunia nyata, seperti klasifikasi, klustering dan asosiasi. Aplikasi WEKA ditulis menggunakan hirarki Java class dengan menerapkan OOP (Object Oriented Programming) dan dapat dijalankan hampir di semua platform [11].

\section{Metode Penelitian}

Penelitian kali ini adalah berdasarkan data dari database transaksi Indomaret GKB yang beralamatkan di jalan Jawa Kabupaten Gresik selama bulan juli 2019 dalam bentuk csv. Dari data csv tersebut diolah terlebih dahulu dengan menggunakan Aplikasi Microsoft Excel. Alasan penggunakan Excel adalah untuk dilakukan pre-prosesing dengan cara pivoting yang mengatur pola matrix dan dilakukan perubahan sesuai format yang dapat dibaca oleh Aplikasi WEKA. Setelah sesuai format kemudian di copy paste ke file document baru lalu disave dengan format csv kembali dengan format yang berbeda. Lebih jelasnya seperti gambar berikut: 


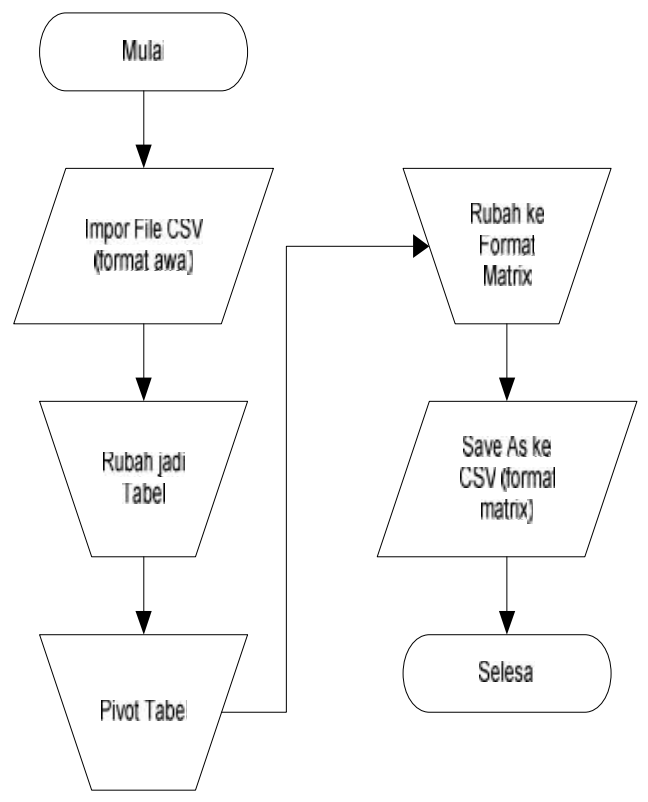

Gambar 2. Flowchart merubah format csv dari data awal ke data yang dapat dibaca oleh WEKA

Selanjutnya adalah proses di WEKA. Langkah awalnya buka aplikasi WEKA, kali ini menggunakan WEKA 3.9. Import file csv yang sudah dibuat tadi kemudian di save ke format untuk aplikasi WEKA yaitu arff. Selanjutnya adalah proses menentukan asosiasi dengan cara klik menu Association => pilih FPGrowth $=>$ tentukan nilai minsup dan minconf $=>$ Klik Process. Langkah terakhir adalah tunggu hingga hasil dari proses akan muncul dan selesai. Lebih jelasnya bisa dilihat di gambar 2 berikut:

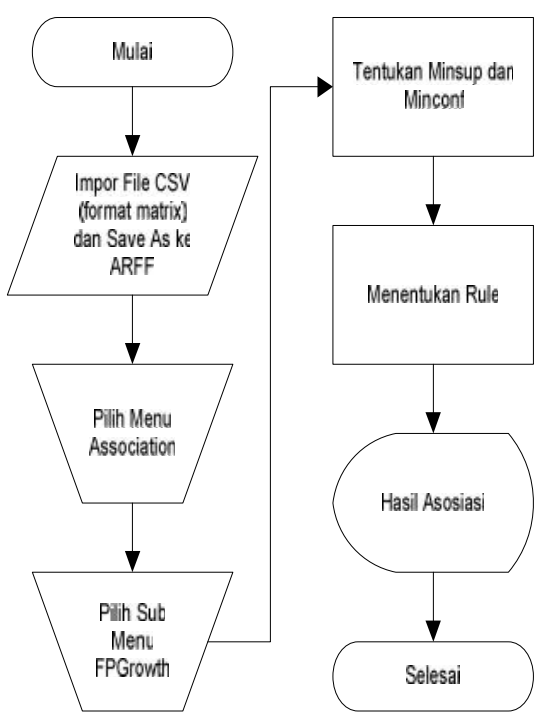

Gambar 3. Flowchart proses penentuan pola asosiasi oleh WEKA

\section{Hasil dan Pembahasan}

Selanjutnya akan dibahas terkait pengolahan data sampai ditemukan pola asosiasi yang dijadikan sebagai hasil akhir pada penelitian. Langkah pertama adalah mengolah data hasil transaksi yang didapatkan yaitu berupa file csv yang kemudian diolah dengan Microsoft Excel menjadi sebuah bentuk tabel seperti berikut:

\begin{tabular}{|c|l|l|l|r|r|}
\hline NO & NO STRUK & KODE & NAMA & QTY & GROSS \\
\hline 1 & STA-00001 & 20034993 & NESCAFE FRENC VNL200 & 1 & 4700 \\
\hline 2 & STA-00001 & $\mathbf{1 0 0 0 3 5 1 7}$ & INDOMI GORENG SPC 80 & 3 & 7500 \\
\hline 3 & STA-00002 & 20034079 & F/FLAG COKLT TPK 225 & 2 & 10800 \\
\hline 4 & STA-00002 & $\mathbf{1 0 0 0 4 0 3 9}$ & SARI ROTI ISI COKLAT & 2 & 12000 \\
\hline 5 & STA-00003 & 10003814 & AQUA AIR MINERAL 600 & 2 & 7000 \\
\hline 6 & STA-00003 & 10010075 & GG SURYA FILTER 16S & 1 & 23200 \\
\hline 7 & STA-00004 & 20045052 & INDOMARET AIR MIN330 & 2 & 4000 \\
\hline 8 & STA-00004 & 20079820 & U MILD ROKOK FLTR 12 & 1 & 12200 \\
\hline 9 & STA-00005 & 20047761 & TOP COFFEE WHTE 10S & 1 & 11200 \\
\hline 10 & STA-00005 & 20068905 & FF SKM PUTIH 560G & 1 & 15500 \\
\hline$\ldots$ & $\ldots$ & $\ldots$ & $\ldots$ & $\ldots$ & $\ldots$ \\
\hline$\ldots$ & $\ldots$ & $\ldots$ & $\ldots$ & $\ldots$ & $\ldots$ \\
\hline 3 & $\ldots$ & $\ldots$ & $\ldots$ & 1 & 19700 \\
\hline 34535 & STC-00643 & 20071827 & RNSO+ML PWD ROSE 770 & & 192000 \\
\hline 34536 & STC-00644 & 20021004 & LACTOGROW 3 BOX 750G & & 19 \\
\hline
\end{tabular}

Tabel 7. Data transaksi yang sudah diolah oleh Excel

Pada Tabel 7. didapatkan tabel sebuah tabel dengan record data yang cukup banyak yaitu 34.537 record. Langkah selanjutnya ialah merubah tampilan Tabel 7. menjadi sebuah tabel baru yang dapat dibaca oleh WEKA. Prosesnya menggunakan salah satu tools milik Excel yaitu Pivot Tabel yaitu mengelompokkan no struk secara horizontal dan item secara vertikal. Hasil pivoting yang dimaksud adalah 
sebagai berikut :

\begin{tabular}{|c|c|c|c|c|c|c|c|c|c|}
\hline NO_STRUK & $\begin{array}{c}\text { NESCAFE } \\
\text { FRENC } \\
\text { VNL200 }\end{array}$ & $\begin{array}{c}\text { INDOMI } \\
\text { GORENG } \\
\text { SPC 80 }\end{array}$ & $\begin{array}{c}\text { F/FLAG } \\
\text { COKLT } \\
\text { TPK 225 }\end{array}$ & $\begin{array}{c}\text { SARI ROTI } \\
\text { ISI } \\
\text { COKLAT }\end{array}$ & $\begin{array}{c}\text { AQUA AIR } \\
\text { MINERAL } \\
\mathbf{6 0 0}\end{array}$ & $\ldots$ & $\ldots$ & $\ldots$ & $\begin{array}{c}\text { MARIZA } \\
\text { STRW JAM } \\
\mathbf{1 7 0}\end{array}$ \\
\hline STA-00001 & Y & Y & $?$ & $?$ & $?$ & $\ldots$ & $\ldots$ & $\ldots$ & $?$ \\
\hline STA-00002 & $?$ & $?$ & Y & Y & $?$ & $\ldots$ & $\ldots$ & $\ldots$ & $?$ \\
\hline STA-00003 & $?$ & $?$ & $?$ & $?$ & Y & $\ldots$ & $\ldots$ & $\ldots$ & $?$ \\
\hline STA-00004 & $?$ & $?$ & $?$ & $?$ & $?$ & $\ldots$ & $\ldots$ & $\ldots$ & $?$ \\
\hline STA-00005 & $?$ & $?$ & $?$ & $?$ & $?$ & $\ldots$ & $\ldots$ & $\ldots$ & $?$ \\
\hline STA-00006 & $?$ & $?$ & $?$ & $?$ & $?$ & $\ldots$ & $\ldots$ & $\ldots$ & $?$ \\
\hline STA-00007 & $?$ & $?$ & $?$ & $?$ & $?$ & $\ldots$ & $\ldots$ & $\ldots$ & $?$ \\
\hline STA-00008 & $?$ & $?$ & $?$ & $?$ & $?$ & $\ldots$ & $\ldots$ & $\ldots$ & $?$ \\
\hline STA-00009 & $?$ & $?$ & $?$ & $?$ & $?$ & $\ldots$ & $\ldots$ & $\ldots$ & $?$ \\
\hline STA-00010 & $?$ & $?$ & $?$ & $?$ & $?$ & $\ldots$ & $\ldots$ & $\ldots$ & $?$ \\
\hline STA-00011 & $?$ & $?$ & $?$ & $?$ & $?$ & $\ldots$ & $\ldots$ & $\ldots$ & $?$ \\
\hline STA-00012 & $?$ & $Y$ & $?$ & $?$ & $?$ & $\ldots$ & $\ldots$ & $\ldots$ & $?$ \\
\hline STA-00013 & $?$ & $?$ & $?$ & $?$ & $?$ & $\ldots$ & $\ldots$ & $\ldots$ & $?$ \\
\hline STA-00014 & $?$ & $?$ & $?$ & $?$ & $?$ & $\ldots$ & $\ldots$ & $\ldots$ & $?$ \\
\hline STA-00015 & $?$ & $?$ & $?$ & $?$ & $?$ & $\ldots$ & $\ldots$ & $\ldots$ & $?$ \\
\hline STA-00016 & $?$ & $?$ & $?$ & $?$ & $?$ & $\ldots$ & $\ldots$ & $\ldots$ & $?$ \\
\hline STA-00017 & $?$ & $?$ & $?$ & $?$ & $?$ & $\ldots$ & $\ldots$ & $\ldots$ & $?$ \\
\hline STA-00018 & $?$ & $?$ & $?$ & $?$ & $?$ & $\ldots$ & $\ldots$ & $\ldots$ & $?$ \\
\hline STA-00019 & $?$ & $?$ & $?$ & $?$ & $?$ & $\ldots$ & $\ldots$ & $\ldots$ & $?$ \\
\hline STA-00020 & $?$ & $?$ & $?$ & $?$ & $?$ & $\ldots$ & $\ldots$ & $\ldots$ & $?$ \\
\hline$\ldots$ & $\ldots$ & $\ldots$ & $\ldots$ & $\ldots$ & $\ldots$ & $\ldots$ & $\ldots$ & $\ldots$ & $\ldots$ \\
\hline$\ldots$ & $\ldots$ & $\ldots$ & $\ldots$ & $\ldots$ & $\ldots$ & $\ldots$ & $\ldots$ & $\ldots$ & $\ldots$ \\
\hline$\ldots$ & $\ldots$ & $\ldots$ & $\ldots$ & $\ldots$ & $\ldots$ & $\ldots$ & $\ldots$ & $\ldots$ & $\ldots$ \\
\hline STC-00642 & $?$ & $?$ & $?$ & $?$ & $?$ & $\ldots$ & $\ldots$ & $\ldots$ & $?$ \\
\hline STC-00643 & $?$ & $?$ & $?$ & $?$ & $?$ & $\ldots$ & $\ldots$ & $\ldots$ & $?$ \\
\hline STC-00644 & $?$ & $?$ & $?$ & $?$ & $?$ & $\ldots$ & $\ldots$ & $\ldots$ & $?$ \\
\hline
\end{tabular}

Tabel 8 . Tabel yang sudah disesuaikan dengan format matrix

Tabel 8. merupakan tampilan tabel yang sudah disesuaikan dengan format yang dapat dibaca oleh WEKA yaitu format Matrix. Tanda Y pada isi tabel menandakan bahwa item yang bertindak sebagai kolom ada pada no transaksi yang bertindak sebagai baris, sedangkan "?" adalah menandakan bahwa tidak ada transaksi item tersebut di struk tersebut. Dari tabel tersebut dihasilkan 16.235 total struk dengan 3.206 item yang berarti ada 16.236 record atau baris dan 3.207 kolom. Mengapa dibuat seperti ini? Karena tabel bentuk matrix inilah yang dapat diimport dan dibaca oleh aplikasi WEKA. Selanjutnya ialah saveas Tabel 6. tersebut kedalam format csv.

Setelah membuat file csv dari Tabel 8. diatas selanjutnya adalah masuk ke tahap prosesing yaitu proses menggunakan aplikasi WEKA.

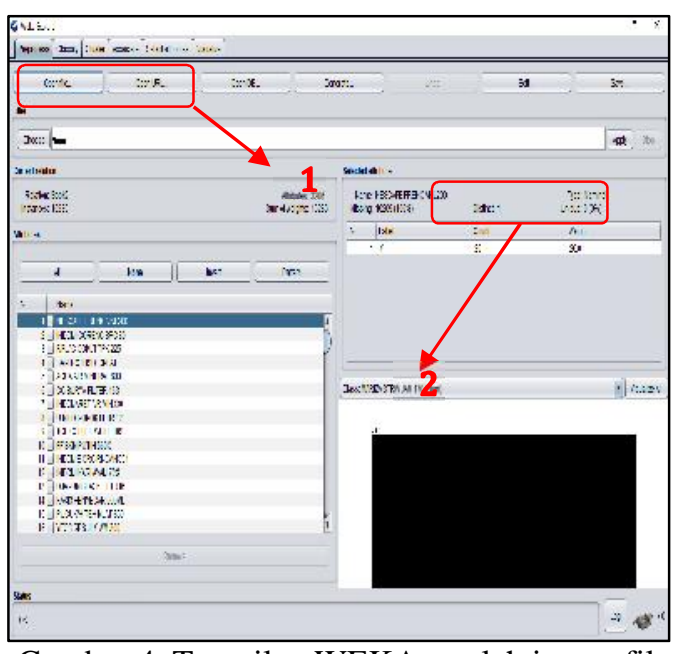

Gambar 4. Tampilan WEKA setelah impor file

Buka aplikasi WEKA pilih Explorer, pada tab Preprocess lalu Open file. Kemudian pilih file csv yang dibuat dari Tabel 6. tadi, setelah proses import berhasil akan tampil seperti Gambar 4. yang ditunjukkan dengan panah no.1. Selain itu juga dapat dilihat jumlah record atau transaksi pada keterangan Sum of weights dan jumlah item pada keterangan Attributes pada Current relation sesuai dengan panah 
no.2. Pada tahap ini save-as data yang berhasil ditampilkan tersebut kedalam format yang dapat dibaca oleh WEKA yaitu arff (untuk memudahkan jika akan kembali melakukan percobaan menggunakan file yang sama).

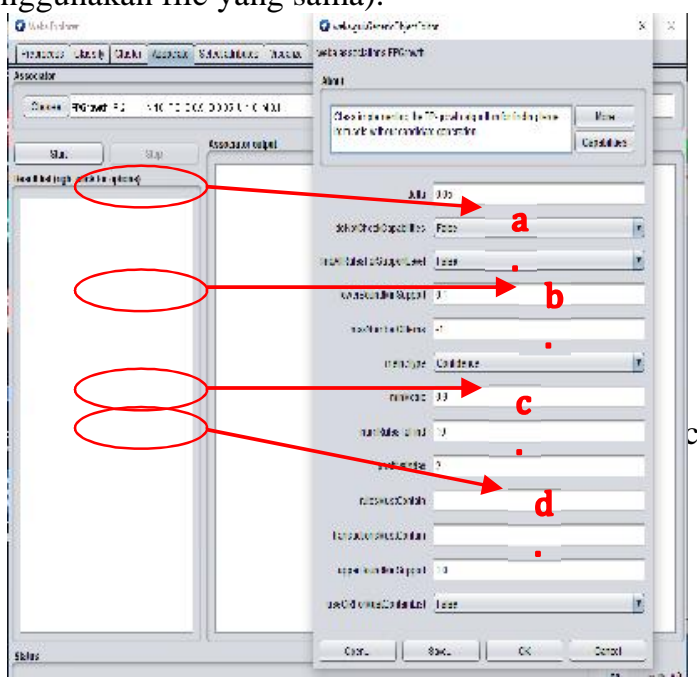

Gambar 5. Menu Asosiasi dan setting FP-Growth

Langkah selanjutnya adalah pergi ke menu Associate lalu pilih Associator dengan FPGrowth... (huruf dan angka dibelakang associator adalah settingan dari metode FPGrowth pada aplikasi ini). Untuk merubah settingan FP-Growth cukup klik 2x pada Associator lalu muncul pop-up seperti Gambar 5. Beberapa keterangan yang terdapat dalam menu setting dan biasa dirubah - rubah diantaranya adalah sebagai berikut :

a. delta untuk membagi menjadi beberapa bagian proses atau split (default: 0.05 artinya membagi menjadi 20 bagian atau 0.05 maksudnya adalah 1/20). Langkah split ini yaitu membagi proses menjadi beberapa bagian kecil kemudian digabungkan kembali menjadi satu kesatuan saat hasil sudah ditemukan.

b. lowerBoundMinSupport adalah untuk menentukan nilai minimum support. Textbox ini yang biasanya dirubah (minsup default : 0.1 atau $10 \%$ )

minMetric adalah untuk menentukan nilai minimum metric. Jika pada metricType adalah Confidence maka yang dimaksud minMetric ini adalah minimum confidence atau minconf. Textbox ini juga yang biasanya dirubah (minconf default : 0.9 atau $90 \%$ )

d. minRulesToFind untuk menampilkan hasil dari record yang berhasil ditemukan atau dihasilkan. Secara default WEKA akan menampilkan 10 baris atau record teratas.

Berikut ini merupakan hasil dari proses dengan menggunakan settingan default:

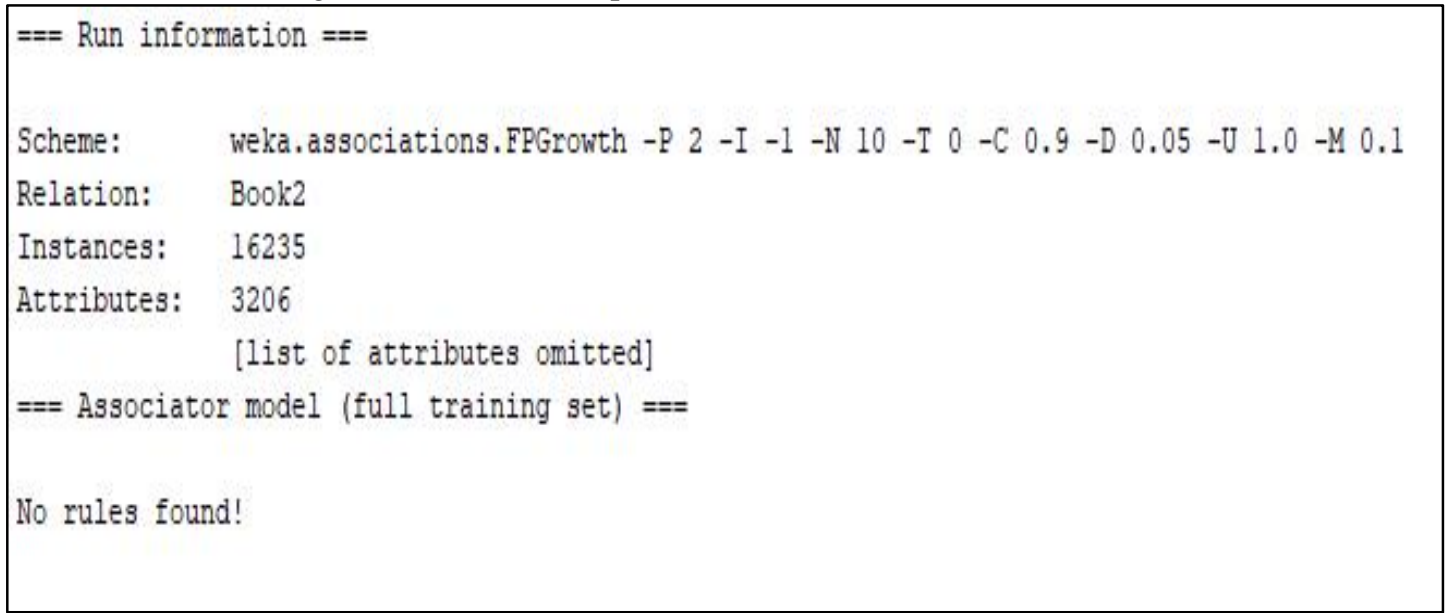

Gambar 6. Percobaan proses menggunakan settingan default

Dilakukan percobaan dengan settingan default dari WEKA dan ternyat hasil yang didapatkan adalah tidak ada. Itu berarti tidak ada data yang memenuhi settingan minsup (0.1) dan minconf (0.9). Kemudian dicoba-coba rubah setting minsup dan minconf hingga beberapa kali hingga muncul hasil yang dianggap yang terbaik bagi penulis. 


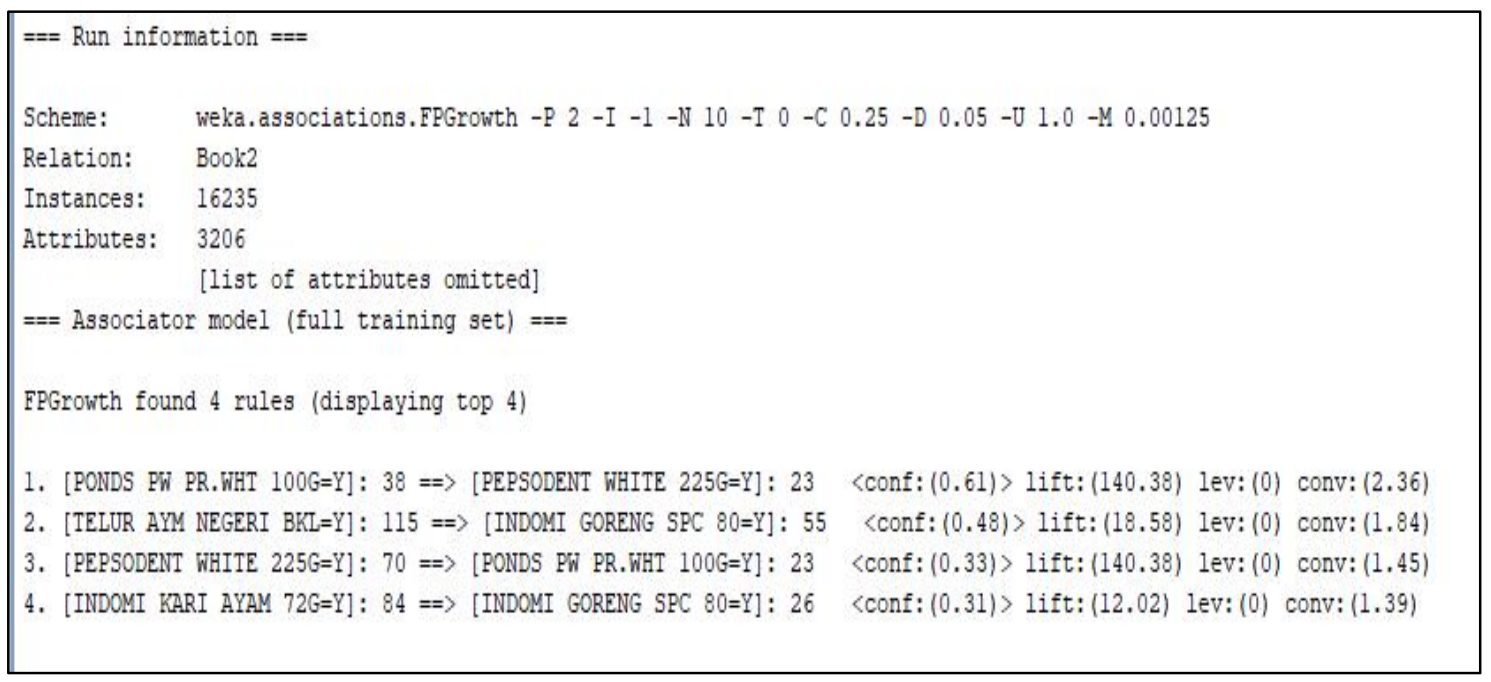

Gambar 7. Hasil akhir yang didapatkan

Setelah melewati beberapa percobaan tidak ketemu juga, akhirnya pada Gambar 7 didapat hasil yang muncul. Settingan untuk Gambar 7 adalah minsup sebesar 0.00125 atau $0.125 \%$ dan minconf sebesar 0.25 atau $25 \%$. Terdapat 4 Rule yang didadapatkan sebagai berikut :

- $\quad$ Ponds PW Pr.Wht 100gr terdapat transaksi sebanyak 38 kali dan 23 kalinya terdapat item Pepsodent White 225gr yang terdapat bersama dalam 1 transaksi dengan nilai confidence adalah 0.61 atau 61\%. Yang berarti jika membeli Ponds PW 100gr berpeluang $61 \%$ akan juga membeli Pepsodent White 225gr.

- $\quad$ Telur Ayam terdapat transaksi sebanyak 115 kali dan 55 kalinya terdapat item Indomie goreng 80 gr yang terdapat bersama dalam 1 transaksi dengan nilai confidence adalah 0.48 atau $48 \%$. Yang berarti jika membeli telur ayam negeri berpeluang $48 \%$ akan juga membeli indomie goreng $80 \mathrm{gr}$.

- Pepsodent White $225 \mathrm{gr}$ terdapat transaksi sebanyak 70 kali dan 23 kalinya terdapat item Ponds PW Pure White 100gr yang terdapat bersama dalam 1 transaksi dengan nilai confidence adalah 0.33 atau 33\%. Yang berarti jika membeli Pepsodent White 225gr berpeluang 33\% akan juga membeli Ponds PW Pure White 100gr.

- Indomie Kari Ayam terdapat transaksi sebanyak 84 kali dan 26 kalinya terdapat item Indomie goreng $80 \mathrm{gr}$ yang terdapat bersama dalam 1 transaksi dengan nilai confidence adalah 0.31 atau $31 \%$. Yang berarti jika membeli indomie kari ayam berpeluang $31 \%$ akan juga membeli indomie goreng 80gr.

\section{Kesimpulan}

Untuk tingkat penjualan minimarket besar seperti Indomaret ternyata sangat jarang untuk membeli pasangan item yang sama dalam satu transaksi. Hal itu dibuktikan dengan penelitian dari 1 bulan transaksi yang terjadi di Indomaret GKB untuk menentukan pasangan item yang bersama dibeli dalam satu transaksi hanya memiliki nilai minimum support sangat kecil yaitu 0.00125 atau $0.125 \%$ itupun hanya terdapat 4 pasang item dengan nilai minimum confidence $25 \%$. 4 pasang item yang terpilih diharapkan dapat dijadikan acuan pertimbangan bila ingin melakukan bandage atau bundling item pada minimarket daerah sekitar GKB Gresik. Lalu bila terdapat penelitian serupa disarankan dapat mencoba metode asosiasi yang lain dengan data yang besar dan variatif sehingga hasil yang didapatkan juga lebih akurat dengan harapan dapat diimplementasikan di dunia nyata.

\section{Daftar Pustaka}

[1] Rizka Nurul Arifin. "Implementasi Algoritma Frequent Pattern Growth (FP-Growth) Menentukan Asosiasi Antar Produk (Study Kasus NadiaMart)", Skripsi Fakultas Ilmu Komputer Universitas Dian Nuswantoro, 2015.

[2] Ali Ikhwan, Milfa Yetri, Yohanni Syahra, Jufri Halim, Andysah Putera Utama Siahaan, Solly Aryza and Yasmin Mohd Yacob. "A Novelty of Data Mining for Promoting Education Based on FP-Growth Algorithm", International Journal of Civil Engineering and Technology (IJCIET), Hal 1660-1667, 2018.

[3] Ali Ikhwan, Dicky Nofriansyah dan Sriani. "Penerapan Data Mining dengan Algoritma FP- 
Growth untuk Mendukung Strategi Promosi Pendidikan (Studi Kasus Kampus STMIK Triguna Dharma)", Jurnal SAINTIKOM vol.14, No.3, Hal 211-226, 2015.

[4] Sigit Kurniawan, Windu Gata dan Hari Wiyana. "Analisis Algoritma FP-Growth untuk Rekomendasi Produk pada Data Retail Penjualan Produk Kosmetik (Studi Kasus : MT Shop Kelapa Gading)", Seminar Nasional Teknologi Informasi dan Komunikasi 2018 (SENTIKA 2018), Hal 61-69, 2018.

[5] Dyah Pramesthi Larasati, Muhammad Nasrun dan Umar Ali Ahmad. "Analisis dan Implementasi Algoritma FP-Growth pada Aplikasi SMART untuk Menentukan Market Basket Analysis pada Usaha Retail (Studi Kasus : PT. X)", e-Proceeding of Engineering Telkom University : Vol.2, Hal 749-755, 2015.

[6] Dio Prima Mulya. "Analisa dan Implementasi Association Rule dengan Algoritma FP-Growth dalam Seleksi Pembelian Tanah Liat (Studi Kasus : PT. Anveve Ismi Berjaya)", Jurnal Teknologi dan Sistem Informasi Bisnis Unidha Vol.1, No.1, Hal 47-57, 2019.

[7] Goldie Gunadi dan Dana Indra Sensuse. "Penerapan Metode Data Mining Market Basket Analysis terhadap Data Penjualan Produk Buku dengan Menggunakan Algoritma Apriori dan Frequent Pattern Growth (FPGrowth) : Studi Kasus Percetakan PT. Gramedia", Jurnal TELEMATIKA MKOM Vol.4, No.1, Hal 118-132, 2012.

[8] Fitriyani. "Implementasi Algoritma FP-Growth Menggunakan Association Rule pada Market Basket Analysis", E-Journal BSI Informatika Vol.II, No. 1, Hal 296-305, 2015.

[9] Alfannisa Annurullah Fajrin dan Algifanri Maulana. "Penerapan Data Mining untuk Analisis Pola Pembelian Konsumen dengan Algoritma FP-Growth pada Data Transaksi Penjualan Spare Part Motor", Kumpulan jurnaL Ilmu Komputer (KLIK) Vol.5, No.1, Hal 27-36, 2018.

[10] Ratih Rifaatul Mahmudah dan Eko Aribowo. "Penggunaan Algoritma FP-Growth untuk Menemukan Aturan Asosiasi pada Data Transaksi Penjualan Obat di Apotek (Studi Kasus : Apotek UAD)", Jurnal Sarjana Teknik Informatika Universitas Ahmad Dahlan Vol.2, No.3, 2014.

[11] Slamet Pujiono, Armadiyah Amborowati dan M. Suyanto. "Analisis Kepuasan Publik Menggunakan Weka dalam mewujudkan Good Governance di Kota Yogyakarta”, Jurnal Data Manajemen dan Teknologi Informasi (DASI) AMIKOM Vol.14, No.2, 2013.
[12] S. Susmanto, Z. Zulfan, and M. Munawir, "Sistem Penerapan Fuzzy Multi Attribute Decision Making (MADM) Dalam Mendukung Keputusan Untuk Menentukan Lulusan Terbaik Pada Sekolah Tinggi Teknik Poliprofesi Medan," J. Nas. Komputasi dan Teknol. Inf., vol. 1, no. 1, 2018.

[13] S. Al Syahdan and A. Sindar, "Data Mining Penjualan Produk Dengan Metode Apriori Pada Indomaret Galang Kota," J. Nas. Komputasi dan Teknol. Inf., vol. 1, no. 2, 2018. 